\title{
Corporate communication to promote consumers' social responsibility?
}

\author{
Companies have discovered Consumers' Social \\ Responsibility (CnSR). Within CnSR communi- \\ cation consumers are addressed upon their \\ individual responsibility for a behavioural \\ change towards sustainability. Can CnSR \\ communication strengthen sustainable \\ consumption in the mainstream or is it \\ mere greenwashing? \\ By Vera Fricke and Ulf Schrader
}

C onsumers are increasingly confronted with communicated sustainability commitment of companies. Under the claim of Corporate Social Responsibility (CSR) companies contribute to the sustainability paradigm. While having started in niche markets CSR has meanwhile entered the agenda of companies in the mainstream (Fricke/Schrader 2009). However, CSR engagement stays often invisible to consumers as the added ecological and social value is not necessarily reflected within the product or service. To make the respective engagement transparent and to enable purchase decisions based on sustainability aspects, CSR communication becomes key factor in distributing CSR activities towards internal and external stakeholders (Du et al. 2010). CSR communication represents the interface between corporate sustainability activities and consumers' sustainable consumption choices.

Figure 1: New Type of Communication for Sustainable Consumption

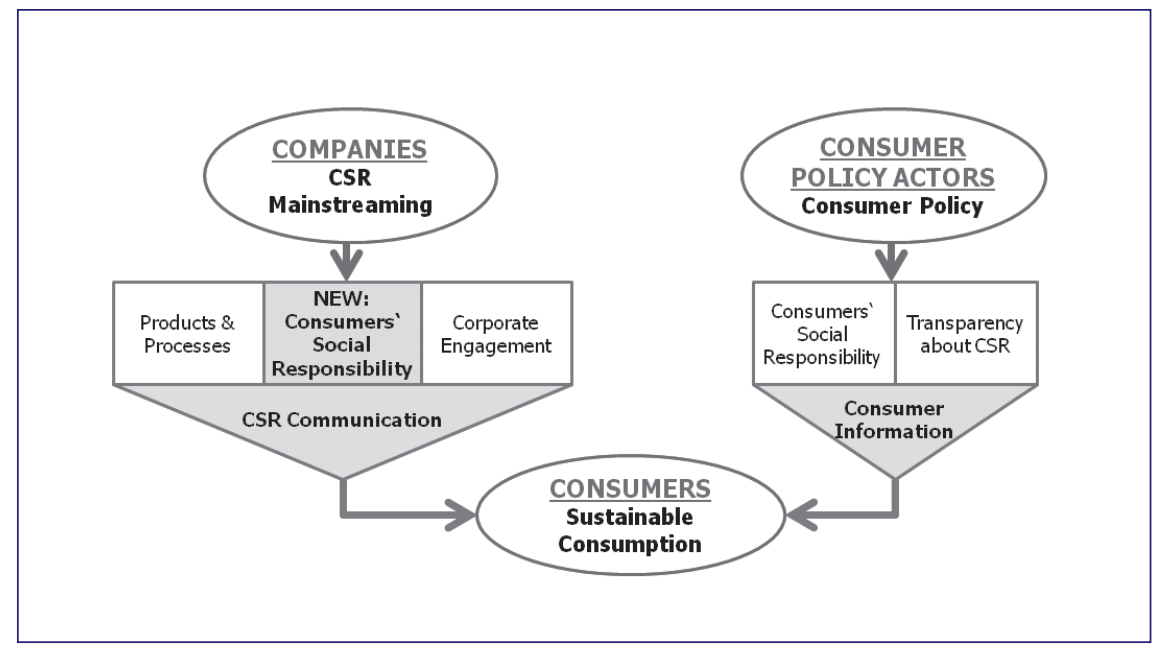

Source: author
Until now CSR communication has focused primarily on product and process responsibility as well as on corporate engagement (Schrader et al. 2008). Additionally, consumers received critical information and consultancy on CSR by governmental and non-governmental consumer policy actors (CPAs), e.g. CSR tests by consumer organisations. Furthermore CPAs create awareness about the individual's social responsibility for a behavioural change towards sustainability (see figure 1).

\section{New corporate communication for sustainable consumption}

Recently, companies have amplified their CSR communication and address just like CPAs Consumers' Social Responsibility (Devinney et al. 2006). By providing information and consultancy on behavioural patterns a new pillar of CSR communication arises that communicates beyond mere corporate responsibility but stresses the complementary need for consumers' social and ecological responsibility (see figure 1).

The so-called CnSR communication is a specific form of corporate CSR communication that addresses individuals' responsibility to contribute to sustainable development through sustainable behaviour. For example, the German energy company RWE offers energy saving recommendations on a separate consumer information portal http: //www.energiewelt.de. In the automobile sector Volkswagen encourages responsible mobility behaviour in double-paged advertisements as part of their "Think Blue“ initiative (Volkswagen 2010). Fitting to its core business Volkswagen recommends how to drive energy efficiently with recommendations like „use high gears“ or „check tire pressure“. Additionally, in Volkswagen brochures and commercials behavioural options are encouraged that go beyond the core business and refer to responsible behaviour in daily life, e.g. switching of standby, open windows instead of electric ventilation or urban gardening activities. Hence, through CnSR communication consumers and society in general receive advice on how to act more sustainably. Companies seem to approach consumers from a societal angle as consumer citizens (CCN 2005). By doing so, they show innovative and comprehen- $\rightarrow$ 
sive initiative for sustainability and may increase their credibility and corporate reputation.

Tackling CnSR communication from a marketing perspective it can be located in the scope of social marketing. It aims „to influence a target audience to voluntarily accept, reject, modify, or abandon a behaviour for the benefit of individuals, groups, or society as a whole“ (Kotler et al. 2002). Although social marketing is open to all actors, prominent examples are mainly initiated by governmental or non-governmental organizations. Social marketing campaigns of private corporations are rarely found and even less reflected in academic literature on marketing or sustainable consumption. Nevertheless, CnSR communication that focuses on individual's sustainability behaviour can be understood as social marketing by corporations.

In addition, CnSR communication can also be embedded in the sustainability marketing approach (Belz/Peattie 2009). The marketing objective here is to harmonise corporate aims with a sound ecological and social performance. Sustainability marketing integrates consumer behaviour and touches the usage phase e.g. by dealing with eco-efficient services that can make the product use more environmental friendly. Thus, sustainability marketing includes like CnSR communication corporate activities for a more sustainable consumer behaviour. However, sustainability marketing has hardly considered communication activities for a behavioural change beyond buying behaviour.

Therefore, CnSR communication with its corporate but also societal goal of creating awareness for consumer citizenship behaviour merges sustainability and social marketing. The approach is similar to social marketing activities of CPAs. Consequently, the setting for CPAs changes. The question arises whether CnSR communication opens new pathways towards sustainable consumption or whether it leads towards mere greenwashing.

\section{Chances of CnSR communication for sustainable consumption}

CnSR communication might have high potential for sustainable consumption because of the strong communication power business holds in general. In quantitative terms, the 30 billion Euros German companies spend each year for advertising alone, are about 250 times higher than the total annual budget of Germany's most important consumer organisations (Becker 2009). If it would be possible to re-channel some of the corporate advertising funds it could contribute to an increasing awareness for consumers' responsibility.

In addition to the quantitative communication power, the higher budget often goes along with a more professional and sophisticated quality of communication of corporations compared to CPAs.

CnSR communication might especially strengthen sustainable consumption in the mainstream since new target groups might be reached. Consumers with reservations towards information provided by CPAs might perceive CnSR content as more relevant and credible. If not only the "notorious" green consumer organisations but energy suppliers and the automobile industry ask for energy saving behaviour, than it really must be relevant!

\section{Risks of CnSR communication for sustainable consumption}

The communicated CnSR message content is crucial for the understanding of sustainable consumption. If companies communicate mainly peanuts of sustainable consumption, e.g. control of tire pressure for fuel-saving, rather than key points, e.g. use of alternatives to the car, the claim for sustainable behaviour stays merely rhetoric (Bilharz et al. 2008). Rebound effects might evolve as fuel saved through eco-efficient driving recommendations can be spend for example on driving longer distances (e.g. Hertwich 2005).

Consumer confusion can build up as consumers might question the credibility of the information, compare it to information given by CPA on the same topic and become irritated in their decision-making (Walsh et al. 2007).

Consumers might develop reactance towards advices for sustainable consumption if they perceive that the corporation has no mandate to interfere in their private life beyond the product. Research shows that a low CSR fit leads towards lower acceptance of consumers (Menon/Kahn 2003). Consequently, reactance against $\mathrm{CnSR}$ communication might evolve if the perceived congruence between behavioural suggestions and the core business of the company is low, e.g. car company promoting urban gardening.

All these negative effects might accumulate in a loss in trust and acceptance of CSR communication which might be perceived as greenwashing and reinforce non-sustainable consumption patterns.

\section{Consequences for consumer policy}

Taking those chances and risks into account the overall effect of CnSR communication for sustainable consumption is uncertain. Society and consumers are confronted with a new information agent and CPAs are affected in their work as their setting has changed. In this respect consumer policy needs to deal with the new challenges and opportunities CnSR communication creates for sustainable consumption. The following aspects might help to strengthen the chances of CnSR communication and reduce its risks. CPAs need to:

I become aware of CnSR communication and how it differs from conventional CPA information for sustainable consumption;

I understand the effects of CnSR communication on consumers;

I develop instruments to influence companies and consumers to strengthen positive effects of $\mathrm{CnSR}$ communication and to limit counterproductive outcomes; 
I think about co-operating with business to identify joint communication strategies to promote sustainable behaviour patterns (see the article of Kleinert in this issue). Possible complementary pathways of CnSR communication and consumer information could be developed and marked with credible signs that ease consumers' decision-making processes and empower them to take up responsibility as consumer citizens.

If CPAs take up their mandate to strengthen the chances and to reduce the risks of $\mathrm{CnSR}$ communication they can contribute to mainstreaming sustainable consumption. In this regard companies may be able to complement and partially substitute CPA's consumer information to promote sustainable consumption. However, first empirical investigation shows that there is still a long way to go.

\section{Annotation}

We will further analyze characteristics of CnSR communication, its impact on sustainable consumption and useful strategies for consumer policy within a project funded by the German Ministry for Agriculture, Nutrition and Consumer Protection (2011-2012).

\section{References}

Belz, F.-M. / Peattie, K.: Sustainability marketing: a global perspective. Glasgow 2009.

Becker, T.: Finanzierungsmodelle für die Verbraucherarbeit in Deutschland. Abschlussbericht des Forschungsvorhabens, Stuttgart 2009.

Bilharz, M. / Lorek, S. / Schmitt, K.: Key points of sustainable consumption: Focusing sustainability communication on aspects which matter AND appeal. In: Ken, T.G. et al. (Eds.): Sustainable consumption and production, S. 287-307. Brussels 2008.

CCN (Consumer Citizenship Network) (Ed.): Consumer citizenship education - guidelines (Vol. 1: Higher Education). Hamar, Norway 2005.

Devinney, T. et al.: The other CSR. Stanford Social Innovation Review, Fall 2006, S. 30-37.

Du, S. / Battacharya, C.B. / Sen, S.: Maximising business returns to Corporate
Social Resonsibility (CSR): The role of CSR communication. In: International Journal of Management Reviews 12, 1/2010, S. 8-19.

Fricke, V. / Schrader, U.: CSR-Mainstreaming: Wirkungen und Nebenwirkungen für den nachhaltigen Konsum. In: GAIA - Ökologische Perspektiven für Wissenschaft und Gesellschaft 18, 2/2009, S. 115-118.

Hertwich, E.G.: Consumption and the rebound effect. An industrial ecology perspective. In: Journal of Industrial Ecology 9, 1-2/2005, S. 85-98.

Kotler, P. / Roberto, N. / Lee, N.: Social marketing: improving the quality of life (2nd ed.). Thousand Oaks, California 2002.

Menon, S. / Kahn, B. E.: Corporate sponsorships of philanthropic activities: when do they impact perception of sponsor brand? In: Journal of Consumer Psychology 41, 2003, S. 847-855.

Schrader, U. / Hansen, U. / Schoeneborn, S.: Why do companies communicate with consumers about CSR? Conceptualization and empirical insights from Germany. In: Studies in Communication Sciences 8, 2-3/2008, S. 303-330.

Volkswagen: Mehr wissen, weniger verbrauchen. Think blue. In: Die ZEIT, 15/2010, S. 8-9.

Walsh, G. / Hennig-Thurau, T. / Mitchell, V.-W.: Consumer confusion proneness: scale development, validation, and application. In: Journal of Marketing Management 23, 7-8/2007, S. 697-721.

\section{AUTHORS + CONTACT}

Vera Fricke is researcher and lecturer in the division of 'economic education and sustainable consumption' at Technische Universität Berlin, Germany.

TU Berlin, Fachgebiet Arbeitslehre/Ökonomie und Nachhaltiger Konsum, Franklinstr. 28-29, 10587 Berlin, Tel: +49 3031428770 , E-Mail: vera.fricke@tu-berlin.de

UlfSchrader holds the chair for 'economic education and sustainable consumption' at Technische Universität Berlin, Germany.
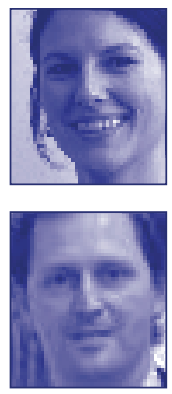

TU Berlin, Fachgebiet Arbeitslehre/Ökonomie und Nachhaltiger Konsum. Tel: +493031428769, E-Mail: schrader@tu-berlin.de
Nachhaltigkeit

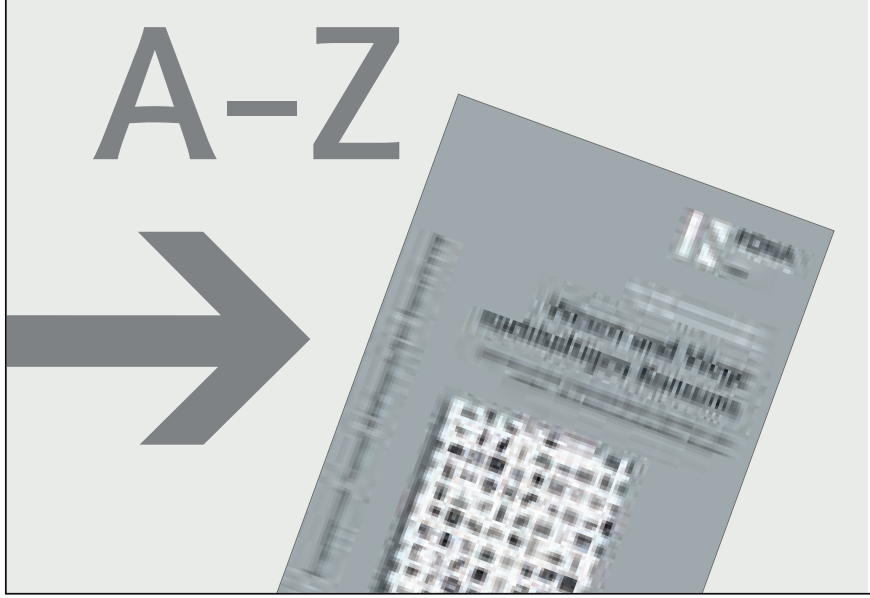

\section{K wie Konsumkultur}

Verändert der Online-Gebrauchtwarenhandel individuelles Konsumverhalten? Wie lassen sich stromverbrauchende Alltagsgewohnheiten am Arbeitsplatz verändern? Diese und andere Fragen zeigen, dass es beim "nachhaltigen Konsum" um weit mehr geht, als um den Kauf von Bio- oder Fair-Trade-Produkten. Die Herausgeberlnnen des vorliegenden Buches gewähren Einblicke in eine Forschungslandschaft, die in unserer konsumorientierten Gesellschaftsordnung zunehmend an Bedeutung gewinnt.

R. Defila, Antonietta Di Giulio, R. Kaufmann-Hayoz (Hrsg.) Wesen und Wege nachhaltigen Konsums

Ergebnisse aus dem Themenschwerpunkt "Vom Wissen zum Handeln Neue Wege zum Nachhaltigen Konsum"

Ergebnisse Sozial-ökologischer Forschung Band 13

498 Seiten, broschiert, 44,95 Euro, ISBN 978-3-86581-296-4

Erhältlich bei

www.oekom.de | oekom@verlegerdienst.de

Die guten Seiten der Zukunft 


\section{Lizenzhinweis}

Die Beiträge in ÖkologischesWirtschaften werden unter der Creative-Commons-Lizenz "CC 4.0 Attribution Non-Commercial No Derivatives" veröffentlicht. Im Rahmen dieser Lizenz muss der Autor/Urheber stets genannt werden, das Werk darf nicht bearbeitet, abgewandelt oder in anderer Weise verändert und außerdem nicht kommerziell genutzt werden. Die digitale Version des Artikels bleibt für zwei Jahre Abonnent/innen vorbehalten und ist danach im Open Access verfügbar. 